\title{
Soil Water Regime in the Tunnel Shelters at Heating Water Filled Shells - Sleeves and Drip Irrigation
}

\author{
Vostrikov V.P.", Pinchuk O.L., Gnatyuk V.N. \\ National University of Water Management and Nature Resources Use, Rivne, Ukraine \\ *Corresponding Author: vladimir_gnatyuk@ukr.net
}

Copyright (C) 2014 Horizon Research Publishing All rights reserved.

\begin{abstract}
The results of studies of soil water regime in the box- section of the surface soil heating by shell-sleeves are given. The peculiarities of formation, dynamics of humidity and holard in the different periods and the effect of drip irrigation on soil water regime which is heated by shell-sleeves are established.
\end{abstract}

Keywords Soil Surface Heating, Shell-Sleeve, Water Regime, Humidity, Holard, Drip Irrigation

\section{Introduction}

Thermal and nuclear power plants, as well as some industrial enterprises in the manufacturing of primary products need constant cooling of technological equipment by the natural water. These companies include metallurgical, chemical, food, cement industries, alcohol, sugar, oil, and other plants. The water that cools the equipment, is heated an average at $8-12{ }^{\circ} \mathrm{C}$, has a temperature $20-25^{\circ} \mathrm{C}$ in spring and brings considerable thermal potential.

Possibilities of useful using of such waste heat water or warm water in agriculture, fish industry have been studied for decades in the industrialized countries.

In particularly, the studies of using of waste heat water for surface heating by ground piping systems, located in the subsurface layer, are known. These studies were conducted in 80 years of last century in the United States of America, France, Germany, Japan, the Soviet Union [1-12]. The aim of research was to determine the possibilities of cooling circulating water in the soil and possibilities to intensify the cultivation of various agricultural plants on soil heating. According to the results of researches significant theoretical and practical results were received, research and industrial systems of underground circulating cooling water of power stations and industrial plants were made.

For example, in Germany the system of soil heating according to "Agroterm" program was designed and applying partly [6], the research systems of underground soil heating were created at Kursk NPP in the Russian
Federation.

However, from point of view of useful using of waste heat water, incapability of underground pipeline systems to provide high thermal effects in the surface layer and to protect plants from frost and low temperatures, that are at night, especially in the early spring, was detected.

\section{The Technology of Surface Soil Heating}

The scientists of NUWMNRU led by Professor V.P. Vostrikov have developed and researched the technology of surface soil heating by flexible polyethylene sleeves.

This method is based on the hypothesis of maximum thermal approaching of resource - warm water as heat carrier to the zone of residence of the plant and immediately to the plant. It is known that the temperature of waste heat water within $20-30{ }^{\circ} \mathrm{C}$ is optimal for the development of the most vegetables and fruits.

The authors have developed, researched and advised for using in practice two kinds of shell- sleeves: as a wide strip with through holes for planting or sowing (Figure 1, photo 1) and as single hoses - pipes that are laid between the rows of plants (Figure 2, photo 2).

On the basis of this technology it has been proposed to create a special system of the surface soil heating ( $\mathrm{SSSH}$ ) and special agricultural enterprises to grow early agricultural products $[1,2]$.

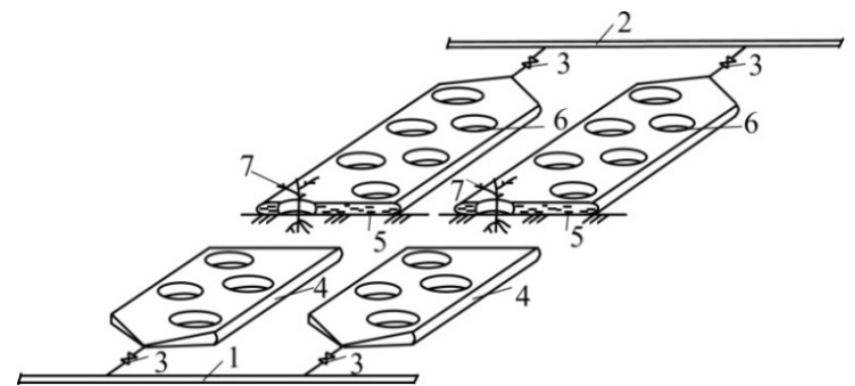

Figure 1. Shell - sleeves in the form of a strip: 1 - manifold outlet, 2 - inlet manifold, 3 - valve, 4 - shell - sleeve, 5 - heat carrier channels, holes for planting; 7 - plants. 


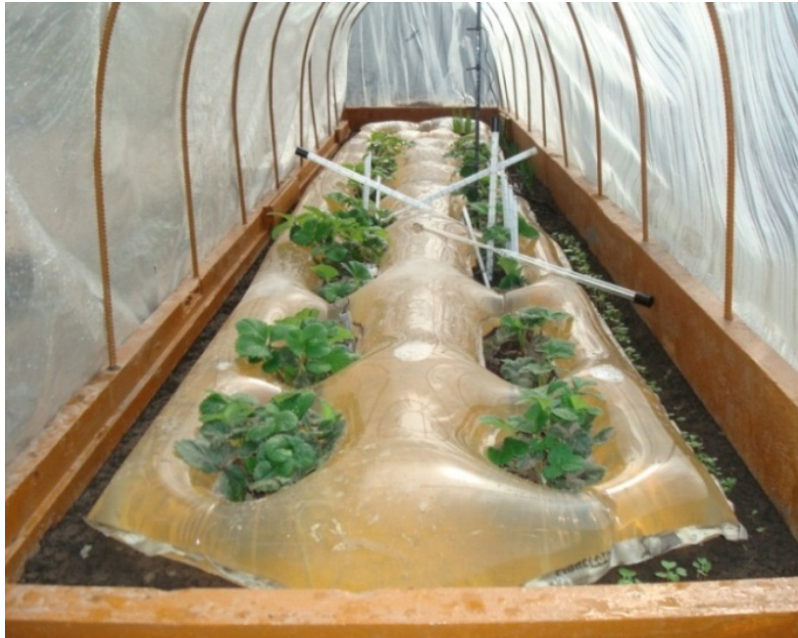

Photo 1. General view of the wide shell - sleeve in the form of a film strip under the tunnel shelter.
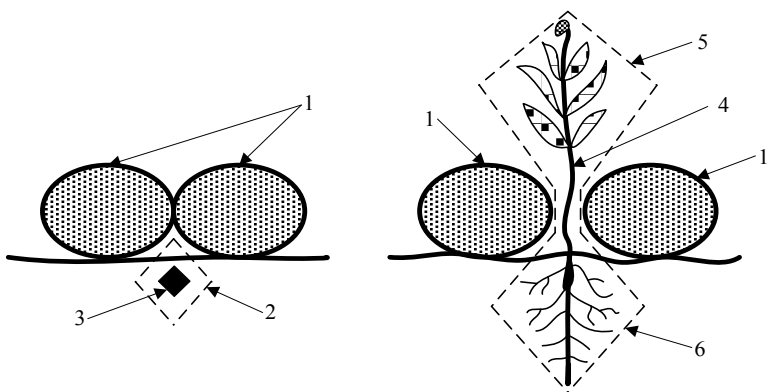

Figure 2. Shell - sleeves in the form of pipelines: 1 - shell - pipes, 2 - zone of seed germination, 3 - seeds, 4 - trunk of plants with leaves, 5 - area of overground part of the plant, 6 - zone of growing of the root system of the plant.

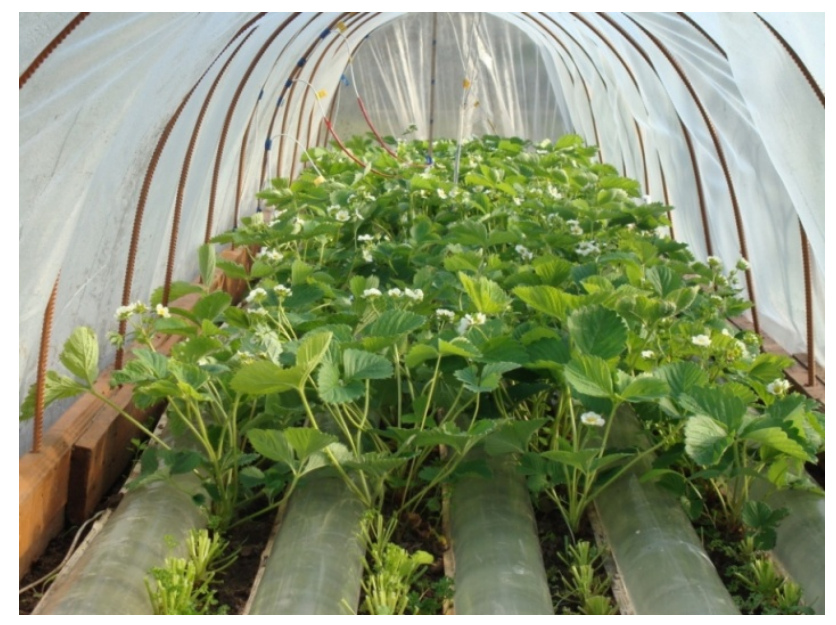

Photo 2. General view of the shell - sleeve in the form of pipelines under the tunnel shelter.

We developed the systems of surface soil heating with shell-sleeves that concern to the seasonal systems of special purpose, at the same time, with improvement of the temperature regime of local areas of soil, they may partly serve as a partial cooling of circulation water for re - use (only during the spring period). Such systems are mounted in spring, are used during March - May, and then are removed till the next season.

In constructive concern SSSH is a technological complete system that includes the individual items such as heaters in the form of shell- sleeves, a network of channels (if there is a necessity), pipelines (trunk, distribution, assembling, wasting, etc. ) with waterworks, pumping stations, regulating basins, an automated water adjustment and irrigation equipment, etc., whose cooperation provides a constant flow of water, the rapid soil heating and surface layer and the required thermal conditions are kept in them throughout the vegetation season of plants.

The main control elements in SSSH are shell- sleeves. Their main task is to transport constantly warm water along the soil surface between plants and soil heating, and surface air. Therefore heaters are concentrated at a certain distance from each other and are combined to increase the efficiency and reliability of the individual box- sections and sections in the box -module.

Box-section consists of a single wide sleeve that warms bed or several narrow shell-sleeves in the form of pipelines which are combined together in a single unit by distributive collector, interceptor and inlet pipe and diverter with shut-off and control valves, automatic equipment (if there is a necessity).

When hot water passes through the flexible shell -sleeves, the processes of heat transfer and heat diffusion are happened in the ground and in the air. As a result, the temperature of soil and surface layer increase, the necessary temperature conditions are created for plant growth and the water in the heating system cools at $1,5-2,0{ }^{\circ} \mathrm{C}$ and is given in the waste network.

Box - module is a system that consists of several box sections, toothings, fittings and auxiliary devices which provide automated work (tapping and dropping of water) with a given regime (consumption, speed, water temperature at the inlet and outlet flow) on the certain bounded area.

Plot of ground (bed) with sleeves is extra equipped by the shelters of the tunnel type which contain light transparent film or plastic, purposely useful using of the thermal energy that circulates in the water-sleeves. General construction scheme of SSSH with shell - sleeves is developed according to the analogy to the structural patterns of drip irrigation and is shown in Figure 3.

Based on the small heads which a system uses, it is designed by low-pressure and gravity feed. Taking away the hot water from waste channel 1 is carried out by using a mobile pumping station 2 and is conveying to the regulating basin 3. Regulator issue 4 lets regulate the flow of water to the pipeline 5 , which distributes it between the inlet pipeline 6 and distributive pipelines 7 box- modules 9 box- section 8 . Network picking 10, drainage 11 and waste pipes (closed collectors) 12 carries out drainage water from the boxmodule 9 - box- section 8 from the flexible shell-sleeves outside SSSH .

For practical use it has been proved and offered to use the section in the form of plots of soil $0.8-1.2 \mathrm{~m}$ width and to $20-25 \mathrm{~m}$ length. Ground in sections is heated either single 
shell - sleeve 0.6-0.8m width when wide-row plants are grown, or 4-5 shell - pipelines $80-100 \mathrm{~mm}$ by diameter when narrow-row plants are grown.

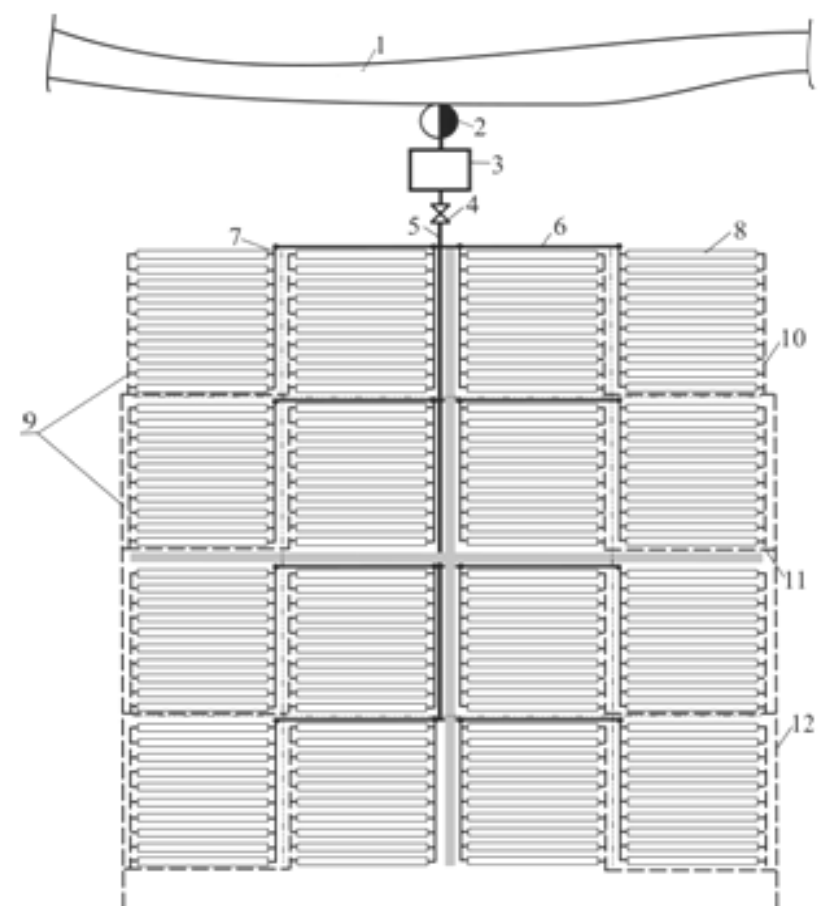

Figure 3. Construction scheme of SSSH - with shell- sleeves : 1 - channel of warm water; 2 - pumping station; 3 - regulating basin ; 4 - regulator issue; 5 - trunk pipeline; 6 - inlet pipe; 7 - distributive pipeline; 8 - box- section with shell-sleeves; 9 - box- modules; 10 - picking pipeline; 11 - drainage pipeline; 12 - waste pipes (channel ).

For the first time I.V. Romanyuk investigated the research of efficiency of the surface heating by wide sleeves warm-exchangers on the territory of Volyn region and in the simulation of waste water's temperature of Rivne NPP [13]. It has been proved that the surface heating under the condition of the use of additional soil protection by shelter tunnel type can increase the temperature of the upper layer of open ground at $12 \ldots 16^{\circ} \mathrm{C}$ and surface air at $7 \ldots 11^{\circ} \mathrm{C}$.

The technology of thermal melioration of soil by surface heating sleeves warm-exchangers with the use of waste heat water showed a high efficiency which stimulated further scientific research and a detailed design for implementation in the agricultural sector.

In the researches of O.L. Pinchuk study designs and parameters of surface heating on the basis of single plastic sleeves-heat have been justified. It has been determined that change of the modified form of conveying elements with wide sleeves warm-exchangers for single shell-sleeves and at the maintain of waste heat water's temperature of Khmelnitsky nuclear power plant allows to create favorable thermal conditions in the soil for growth and development of agricultural crops, including strawberries [14]. The temperature of the warm waste water at Khmelnitsky NPP ranged from $18-20^{\circ} \mathrm{C}$ in March and May.

According to the researches which were conducted the possibilities of active using of heated soil for growing plants in March and April have been revealed. While such possibilities in normal environmental conditions come under conditions of the climate of northern Ukraine in May. Accordingly, the first harvest of green vegetables may be obtained from the heated soil in early April, and strawberries - at the end of April, so 30-40 days earlier than under normal conditions.

Soil surface heating alters thermal regime of the soil and surface air and thus affects other regimes of ground, including water. The study of soil water regime in the application of melioration work was engaged a generation of scientists, in particular, it needs accenting a significant contribution to the study of this subject was made by prof. A.M. Yangol, P.I. Kovalenko, M.I. Romashchenko, A.M. Rokochynskiy, V.A. Stashuk and others.

At the same time, at present stage a question of further study on the influence of surface heating on the water regime of the soil needs researching, especially its formation in the growing season and the distribution of humidity in the blocksection SSSH.

\section{Methods of Research}

The research was conducted by full-scale experiment on black soil at the private agricultural enterprises in Rivne district, Rivne region, Ukraine, in which constant soil heating was being carried out during March-May 2011 and 2012. Comparative researches were carried out in two variants: surface heating by pipeline shell-sleeves with drip irrigation and control - open ground without artificial heating and drip irrigation (natural conditions).

Soil heating system has been made with shell-sleeves with a diameter $100 \mathrm{~mm}$, a length $6.5 \mathrm{~m}$, cart and tap warm water has been carried through the plastic manifolds with a length of $1 \mathrm{~m}$ and a diameter of $100 \mathrm{~mm}$ (Figure 4).

In the experimental plot measuring of the temperature of water in the box- section SSSH, soil at different depths, surface layer at different altitudes were performed; soil and air humidity, speed and water flow in the shell-sleeves, development and harvest of strawberries were observed.

The collection of temperature data of plants environment was carried out by electric thermometer using the developed automated data collection system (ADCS). Its foundation is a personal computer (PC) with the installed SCADA- system Trace Mode 6.

For the purpose to approach research to work conditions in the heating system (experimental block-section) the regime of circulating water of Khmelnitsky nuclear power plant has been designed and the temperature was changed from 20 to $35^{\circ} \mathrm{C}$. The methodology of the research is given in [16].

Studies of soil water regime in a block-section SSSH has been conducted through systematic observations of rainfall and soil humidity. For the purpose to study the nature of the distribution of humidity in the soil profile, estimation of humidity of plants, sampling has been carried out to determine their humidity by thermostat-weight method on 
two types of research - in the block section SSSH and the control area without heating. The selection of soil samples has been carried out by a microdrill on the operational sites located at a distance of $1.0 \mathrm{~m}$ from the place of measuring soil temperature. In this case, samples were selected in the area between the shell-sleeves and the humidity was calculated as the average for that zone. Determination of soil humidity was held once or twice in a decade every $10 \mathrm{~cm}$ to a depth of $0.5 \mathrm{~m}$ to 3 - times repetition. In certain periods soil humidity was defined layer - by - layer to a depth of $1.0 \mathrm{~m}$ Besides, determination of soil humidity was carried out before and after watering in layers $0-0,05,0-10,10-20,20-30,30-40$, 40-50 3 - times repetition.

Water - physical and thermal characteristics of research black soil spot are given in Table 1 .

In the research area, as the main agricultural crop-indicator, strawberries early Italian variety Cleary have been used, plants of which were planted in the dense rows with a distance of $20 \mathrm{~cm}$ between rows and $15 \mathrm{~cm}$ between plants in rows. Besides, the reaction of such plants as the green onion pen, dill, parsley, radishes, lettuce, tomato and cabbage seedlings have been checked for early spring heating.

\section{The Results of Research}

Observations have found that heating of the soil by continuously passing warm water through a network of shell-sleeves, which have been placed on its surface, has a significant influence on the temperature environment of growth and development of plants.

The greatest effect is observed in the heating contained in the root layer of soil and atmospheric boundary layer in the area of the plant. In the first week of March in the soil layer $0-10 \mathrm{~cm}$ the temperature is reached within $13{ }^{\circ} \mathrm{C}$, which is sufficient for the development and growth of plants.

Sufficient temperature for plant growth is supported in future (Table 2).

Changes in thermal regime cause changes in formation of water regime, there is an intense physical evaporation and transpiration of moisture by plants of the next condensation of moisture on the inside surface of the film and condensate drips on the film. Condensate that drips down on the inner surface of the film and precipitation which drip on the outer surface of the film forms specific water regime of the soil for covering (Figure 5).

Part of humidity that has condensed on the inner surface of the film, falls down on the ground, sleeves and plants, and other part runs down on the side strip of soil, wetting it. These side strips of soil near the first and fifth sleeves are additionally humidified by precipitation which falls into covering outside.

At the same time, as the warm sleeves were placed around plants, the leaves and the stems of plants, and the air around them were dried up a little, so the risk of adverse effects of high humidity on plants in shelters was decreased significantly.

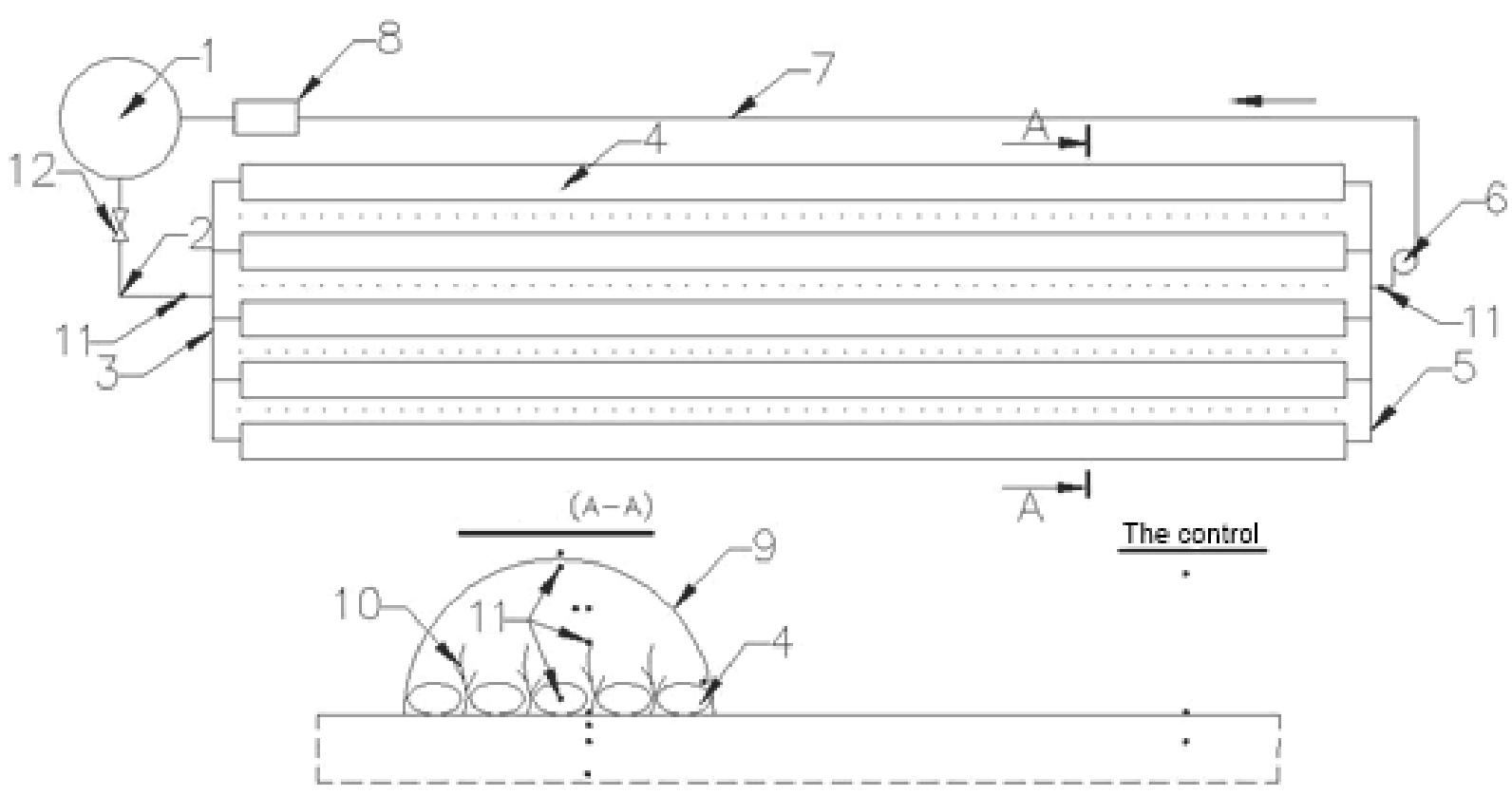

Figure 4. Scheme of full-scale experiment of soil heating: 1 - container of warm water; 2 - coolant supply pipeline; 3 - distributive collector; 4 - shell-sleeve, 5 - picking collector; 6 - pump; 7 - transporting pipeline; 8 - electric heater; 9 - tunnel cover; 10 - plants; 11 - temperature probes; 12 - valve. 
Table 1. Water- physical characteristics of research soil spot

\begin{tabular}{|c|c|c|c|c|c|c|c|c|c|c|}
\hline \multirow{2}{*}{ The layer soil, $\mathrm{cm}$} & \multirow{2}{*}{$\begin{array}{l}\text { The density of the soil, } \\
\qquad \mathrm{g} / \mathrm{cm}^{3}\end{array}$} & \multicolumn{3}{|c|}{ The humidity, $\%$} & \multicolumn{6}{|c|}{ The moisture reserves, $\mathrm{W}, \mathrm{mm}$} \\
\hline & & FMC & LMC & $\mathrm{WH}^{*}$ & FMC & LMC & $0,8 \mathrm{LMC}$ & $0,7 \mathrm{LMC}$ & $0,6 \mathrm{LMC}$ & WH \\
\hline $0-5$ & 1,16 & 44,60 & 32,10 & 10,80 & 25,9 & 18,6 & 14,9 & 13,0 & 11,2 & 6,3 \\
\hline $5-10$ & 1,17 & 44,20 & 31,80 & 10,80 & 25,9 & 18,6 & 14,9 & 13,0 & 11,2 & 6,3 \\
\hline $10-20$ & 1,20 & 42,40 & 29,60 & 10,70 & 50,9 & 35,5 & 28,4 & 24,9 & 21,3 & 12,8 \\
\hline $20-30$ & 1,22 & 41,70 & 28,90 & 10,60 & 50,9 & 35,3 & 28,2 & 24,7 & 21,2 & 12,9 \\
\hline $30-40$ & 1,24 & 40,40 & 27,60 & 10,30 & 50,1 & 34,2 & 27,4 & 24,0 & 20,5 & 12,8 \\
\hline $40-50$ & 1,24 & 39,90 & 26,40 & 9,80 & 49,5 & 32,7 & 26,2 & 22,9 & 19,6 & 12,2 \\
\hline $\begin{array}{l}\text { Average / } \\
\text { sum }\end{array}$ & 1,2 & 42,20 & 29,40 & 10,50 & 253,1 & 175,0 & 140,0 & 122,5 & 105,0 & 63,3 \\
\hline
\end{tabular}

* WH - the wilting humidity

Table 2. The average temperature per decade of soil at different depths in the box- section and the control region ( 2011 )

\begin{tabular}{|c|c|c|c|c|c|c|c|c|c|c|}
\hline \multirow{3}{*}{$\begin{array}{l}\bar{F} \\
\text { 苛 }\end{array}$} & \multirow{3}{*}{ 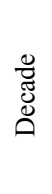 } & \multirow{3}{*}{$\begin{array}{l}\text { Temperature of } \\
\text { hot water, }{ }^{\circ} \mathrm{C}\end{array}$} & \multicolumn{8}{|c|}{ The depth, cm } \\
\hline & & & \multicolumn{2}{|c|}{0} & \multicolumn{2}{|c|}{10} & \multicolumn{2}{|c|}{20} & \multicolumn{2}{|c|}{40} \\
\hline & & & heating & control & heating & control & heating & control & heating & control \\
\hline \multirow{3}{*}{$\begin{array}{l}\text { 总 } \\
\text { ¿゙ }\end{array}$} & I & 18,7 & 11,7 & $-1,7$ & 11,8 & $-1,5$ & 9,0 & $-1,3$ & 5,4 & $-4,4$ \\
\hline & II & 22,0 & 15,0 & 1,6 & 15,1 & 1,8 & 12,3 & 2,0 & 8,7 & $-1,1$ \\
\hline & III & 23,3 & 18,0 & 4,6 & 17,9 & 4,2 & 15,7 & 3,8 & 10,6 & 1,6 \\
\hline \multirow{3}{*}{$\overline{\bar{z}}$} & I & 23,8 & 19,1 & 8,5 & 18,8 & 8,1 & 16,9 & 7,6 & 12,3 & 5,3 \\
\hline & II & 26,3 & 20,2 & 8,5 & 20,1 & 8,1 & 18,1 & 7,6 & 13,4 & 5,1 \\
\hline & III & 26,6 & 21,8 & 16,1 & 21,6 & 14,4 & 19,7 & 12,8 & 15,2 & 11,7 \\
\hline \multirow{3}{*}{$\stackrel{\vec{J}}{\Sigma^{2}}$} & I & 25,3 & 20,8 & 11,4 & 20,6 & 11,4 & 19,2 & 11,4 & 15,7 & 8,1 \\
\hline & II & 25,9 & 21,9 & 18,2 & 21,8 & 16,8 & 20,4 & 15,3 & 16,7 & 14,2 \\
\hline & III & 23,2 & 20,8 & 22,0 & 21,0 & 20,4 & 20,1 & 18,9 & 17,6 & 16,9 \\
\hline
\end{tabular}

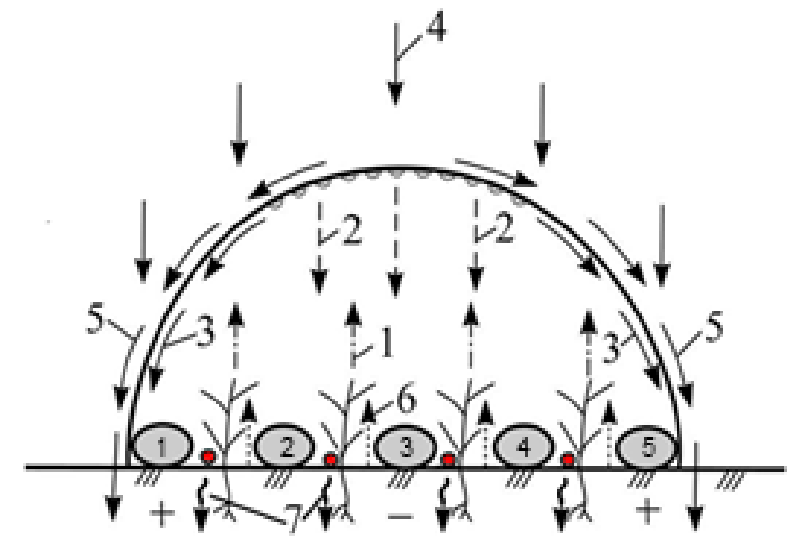

Figure 5. Design of formation of soil water regime that heated by film covering 1 - transpiration of moisture by plants; 2 - condensed moisture that falls on the soil and plants; 3 - condensed moisture that runs down the film; 4 - precipitation; 5 -precipitation that flow down on the film; 6 - evaporation of moisture from the soil surface; 7 - irrigation water from the drop tapes. 
This procedure of the circulation of humidity leads that humidity under the covering is kept in the regulatory lines for a long time, the soil near the side edges is additionally humidified and the strips of soil between 2 and 3 and 4 and 5 sleeves lose partially moisture (dry up).

On sunny days the temperature in the shelter can be raised to critical, dangerous boundaries for plants $\left(40-45^{\circ} \mathrm{C}\right)$, so the forced ventilation of tunnels was carried out in those days. This caused opening the film at the ends of tunnels and lateral side with increasing temperature over $30{ }^{\circ} \mathrm{C}$ in shelter.

On cloudy days the shelter remained closed. Intense losses of moisture beyond covering space with air begin during covering is aired. At this time, the root soil dries up and soil needs humidifying additionally.

Try to analyse the dynamics of changes of humidity and holard in soil according to data of the field experiment in 2011-2012.

The general nature of the change of soil moisture in the $0-50 \mathrm{~cm}$ layer is almost identical and on the control, and in the area of the surface heating (Figure 6,7). Humidity is gradually reduced during March-May from a maximum value that equals the full moisture capacity (FMC), which is $42.2 \%$ for soil of research areas in early March, to a minimum - allowable value is $60 \%$ of the least moisture capacity (LMC). The average value of LMC is $29.4 \%$ for soil of research area heating and $0.6 \mathrm{LMC}=17.6 \%$.

Soil humidity in the area of heating in the initial period of the heating system, when the tunnel cover is closed, keeps within LMC, and early warming and thawing out of soil humidity reaches the level FMC. With increasing of soil's temperature during heating, intensive growth of plants (strawberries), increasing evapotranspiration, begins a gradual decrease in soil humidity, especially in the layer 0-10 $\mathrm{cm}$. The greatest losses of soil humidity and drying occur in a layer $0-5 \mathrm{~cm}$. The intensity of the loss of humidity in the area of heating the soil increases with increasing the harvest of strawberries at the end of April and at the same time with increasing the intensity of ventilation of tunnels during the day. At this time, additional measures need conducting for additional soil humidity. During May (harvest has been gathered and film cover has been removed) soil becomes a natural state and soil humidity is gradually reduced during existing heating, it requires constant monitoring of soil humidity and, if it is necessary, supplying certain portions of water for humidification.
Analysis of observational data connect with the dynamics of control soil humidity shows that the largest humidity is observed at the beginning of the calculating period, and the lowest - in the end. High soil humidity at the beginning of the calculating period is determined by saturating it with humidity during snowmelt and heavy spring rains and decreasing of humidity during the calculating period is influenced by its evaporation from the soil, increasing of transpiration and water using by plants.

In the control plot, which was not heated, soil humidity decreased gradually, but in March and till until mid-April it is about LMC. Humidity begins to reduce in the control soil from the middle of April, when the temperature increases significantly in the experimental plot.

Increasing of humidity in the control region depends on the natural rainfall. Significant rainfall in 2011, which fell at the end of April, allowed to increase soil humidity from $15-20 \%$ to $28-30 \%$.

Soil humidity in the control plot decreases gradually later (in May), especially in the layer $0-10 \mathrm{~cm}$ due to increasing of losses for evapotranspiration and lack of rainfall that could cover this deficit.

Similar tendencies occur in changes of holard in soil (Figure 8). The features of holard's formation are the next. There are maximum humidity reserves when soil is heated, ice and snow are melted on the heated soil.

So they reach $47-50 \mathrm{~mm}$ in the layer $0-10 \mathrm{~cm}$ and $0-50$ $\mathrm{mm}$ in the layer 225- $230 \mathrm{~mm}$. By the end of March, they had decreased to $14 \mathrm{~mm}$ in the layer $0-10 \mathrm{~cm}$ and to $128 \mathrm{~mm}$ in the layer $0-50 \mathrm{~cm}$ as a result of heating of systems, intensive evapotranspiration and ventilating of covering.

It was spent more than $35 \mathrm{~mm}$ in the layer $0-10 \mathrm{~cm}$ and about $100 \mathrm{~mm}$ in the layer 0-50 cm in March and April. Such reduction of holard, especially in the upper layer, caused the replenishment of holard and watering in soil. Watering was carried out with the help of drip irrigation that had been installed with drip tapes, located in lines at the plants.

Comparison of changes of holard of the control soil and soil that is heated, affirms that the pattern of these changes is almost the same in the layer $0-20 \mathrm{~cm}$, where the main root system of strawberries is located. However if replenishment of holard on the control takes place naturally, then surface heating requires artificial recharge of humidity, especially at the end of April and May. 


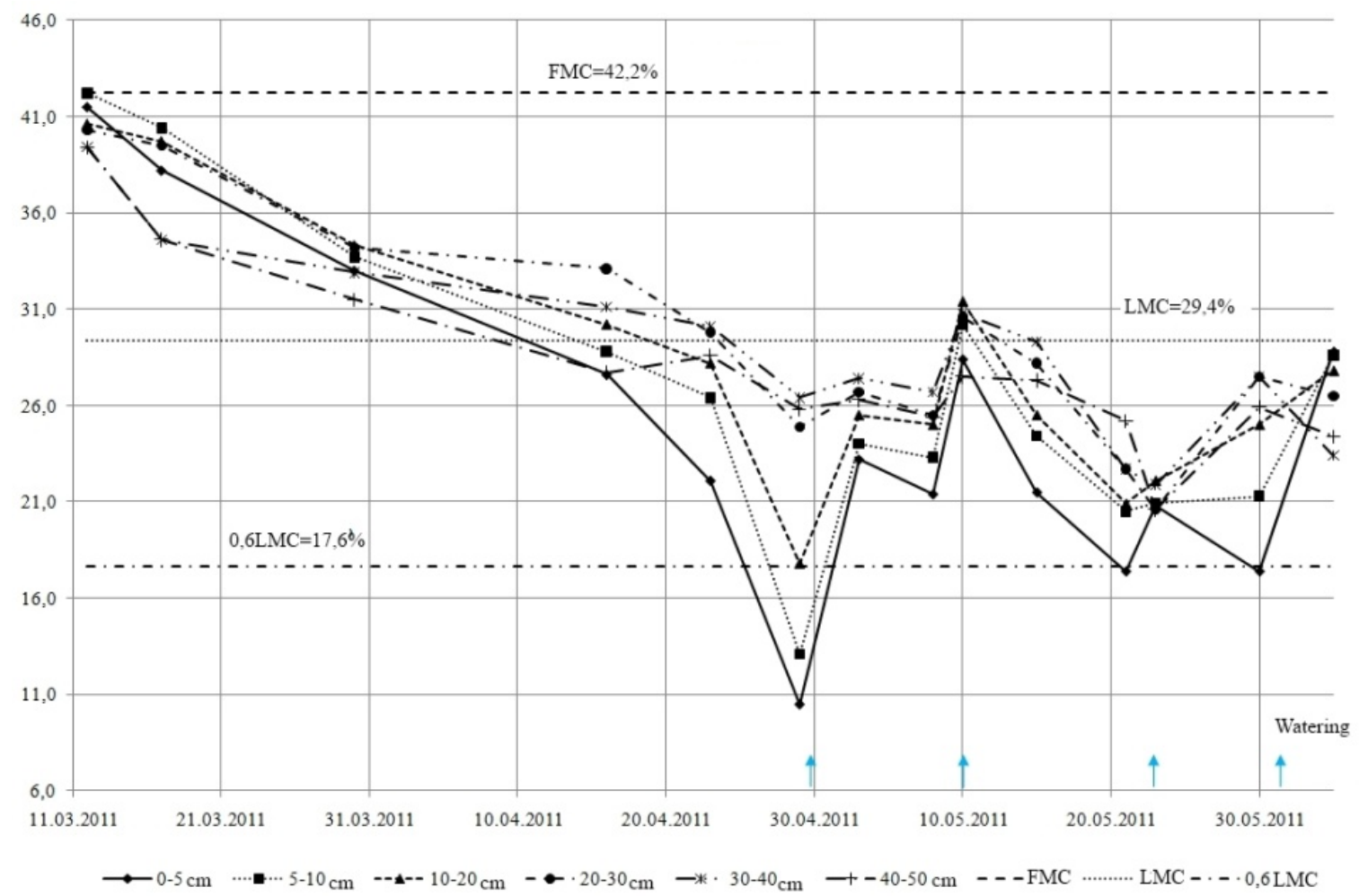

a)

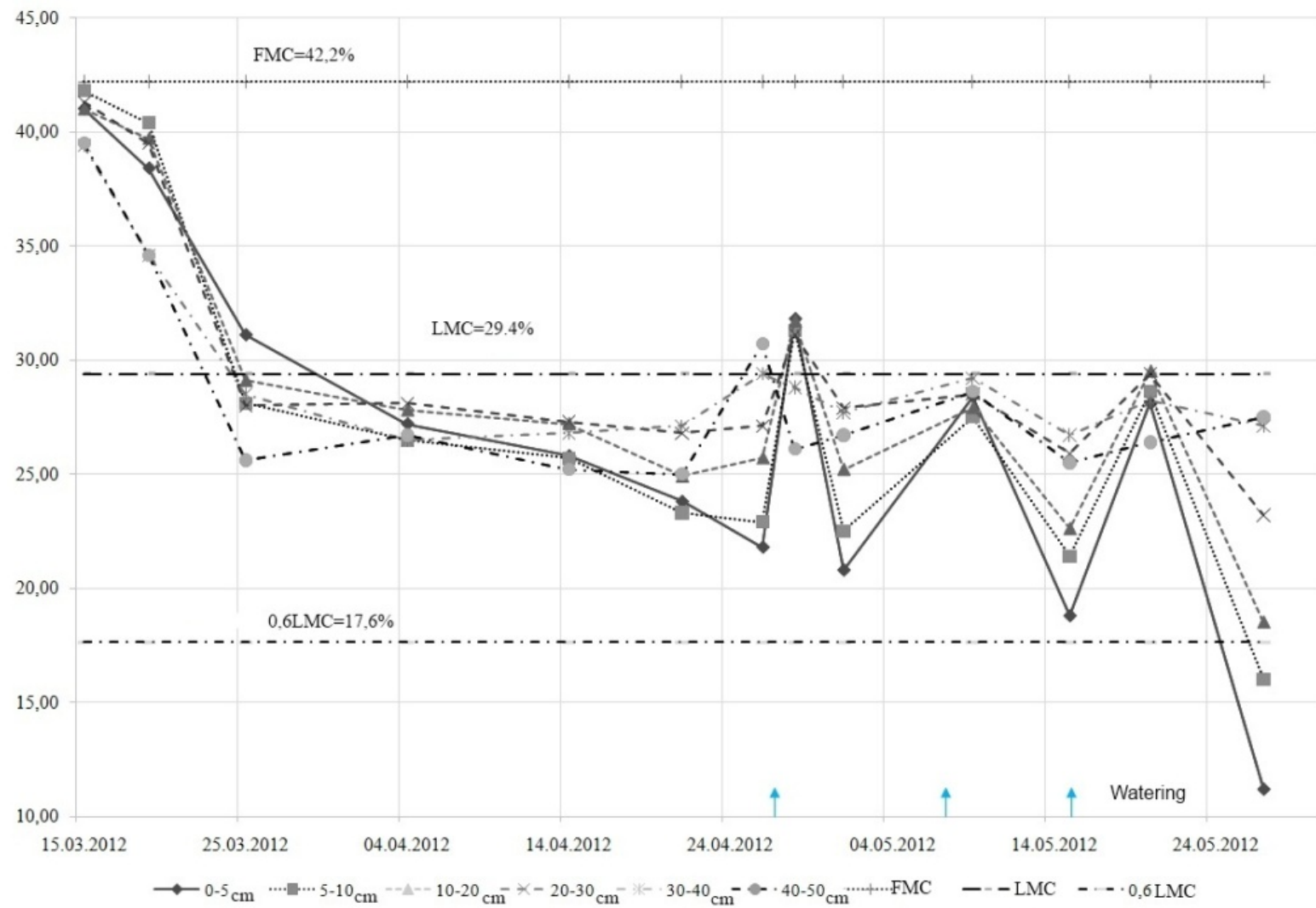

b)

Figure 6. The dynamics of soil humidity in the layer 0-0.5 m in block-section SSSH within: a) 2011 year; b) 2012 year. 


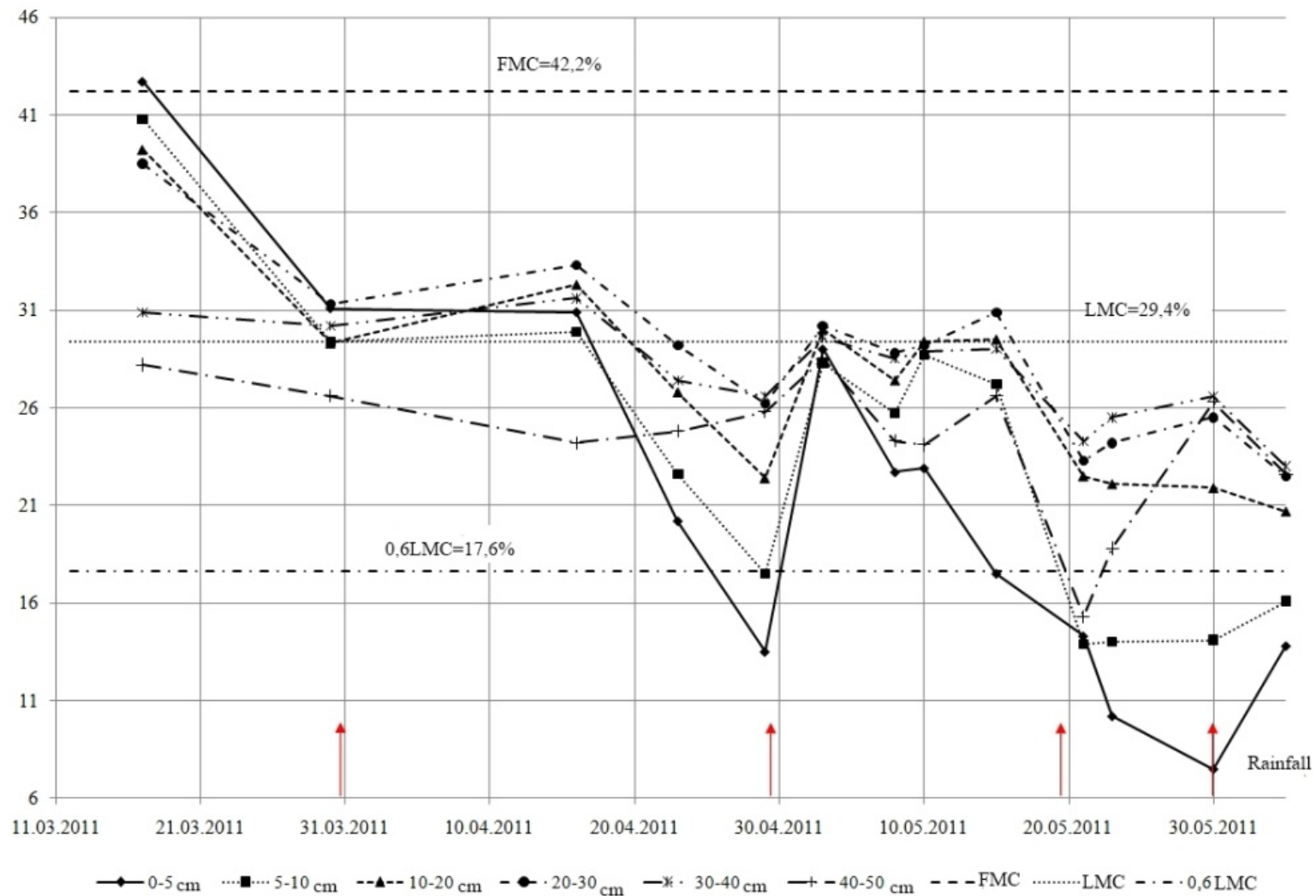

a)

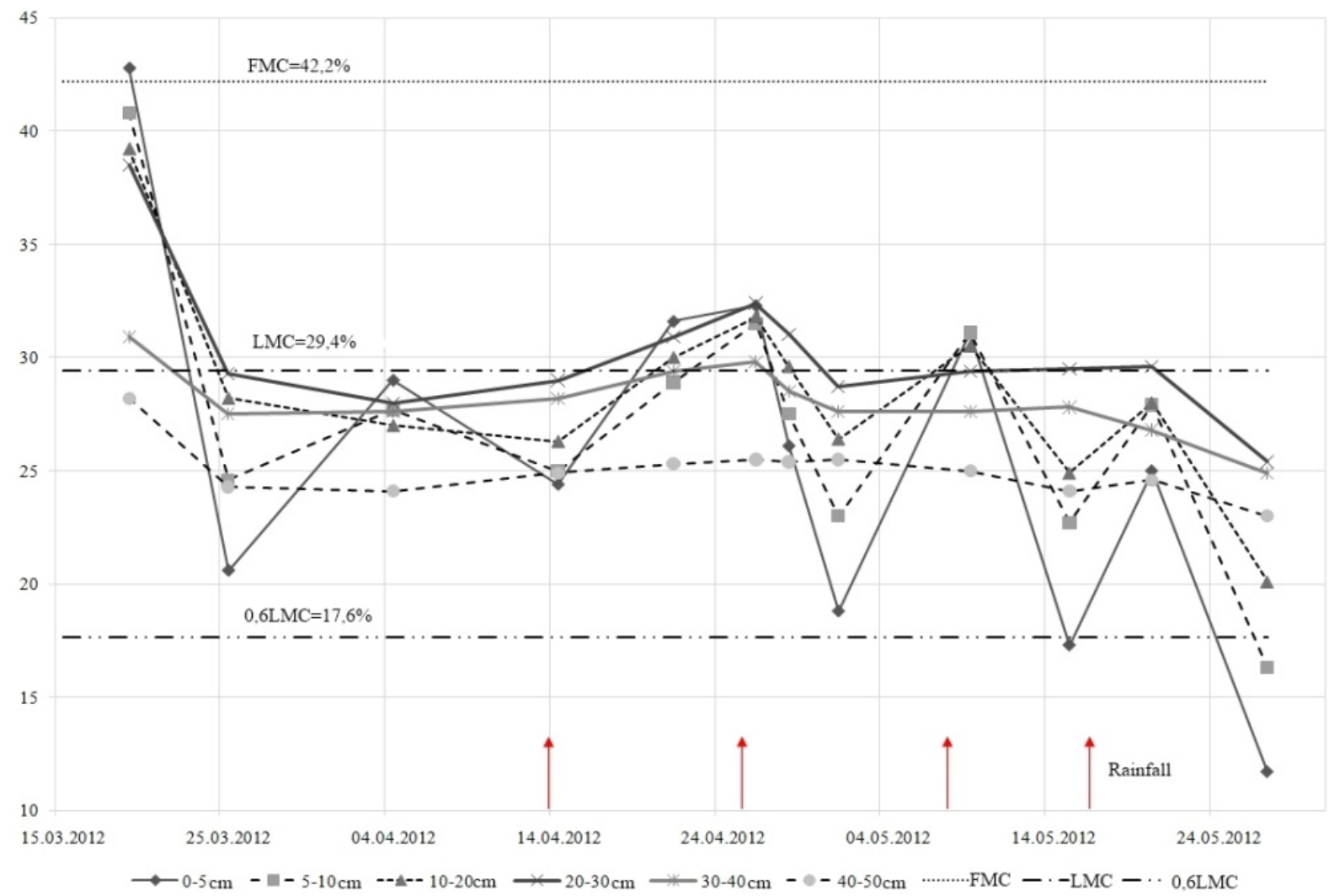

Figure 7. The dynamics of soil humidity in the layer 0-0.5 $\mathrm{m}$ in the control plot within: a) 2011 year; b) 2012year. 


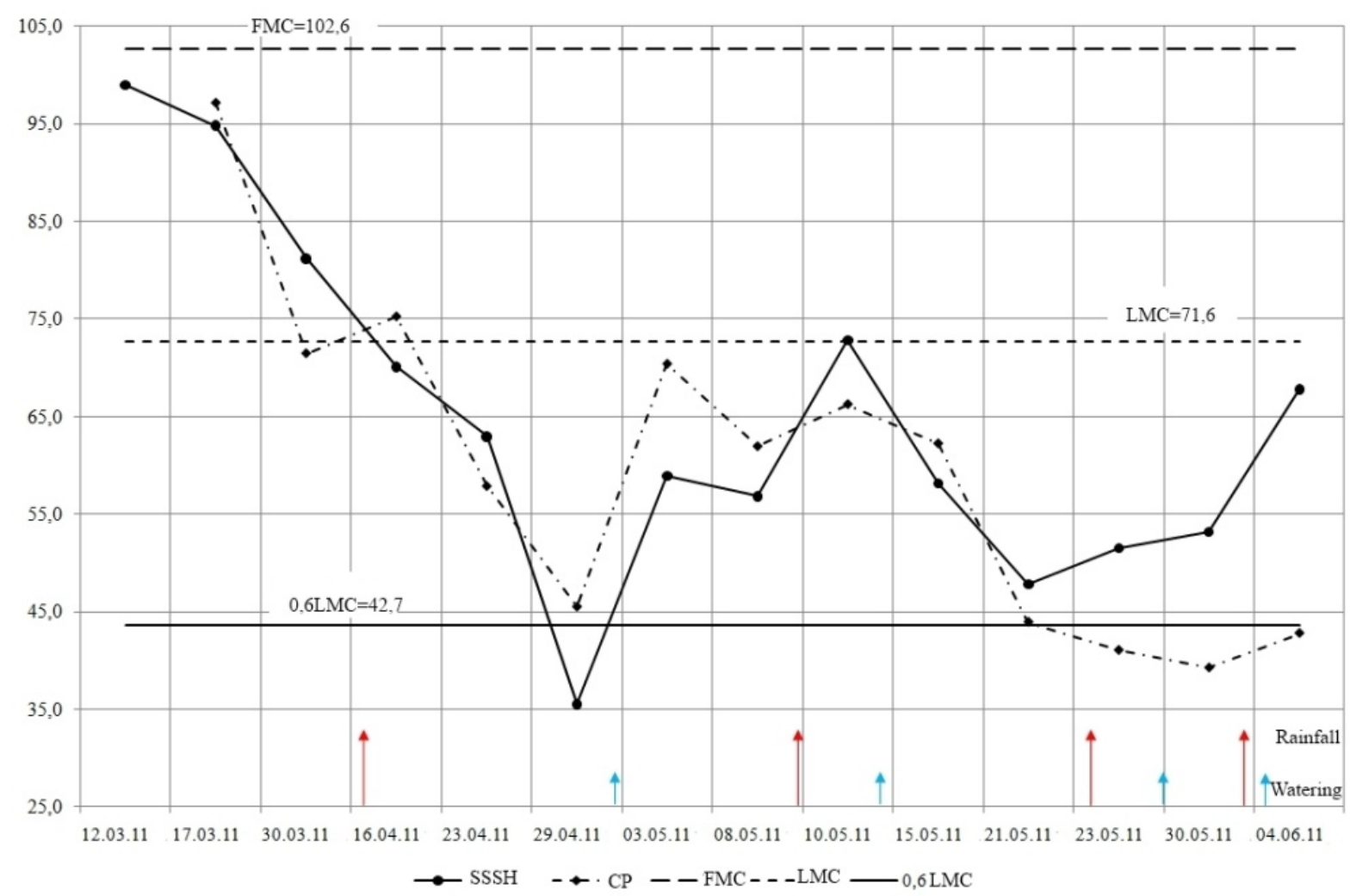

a)

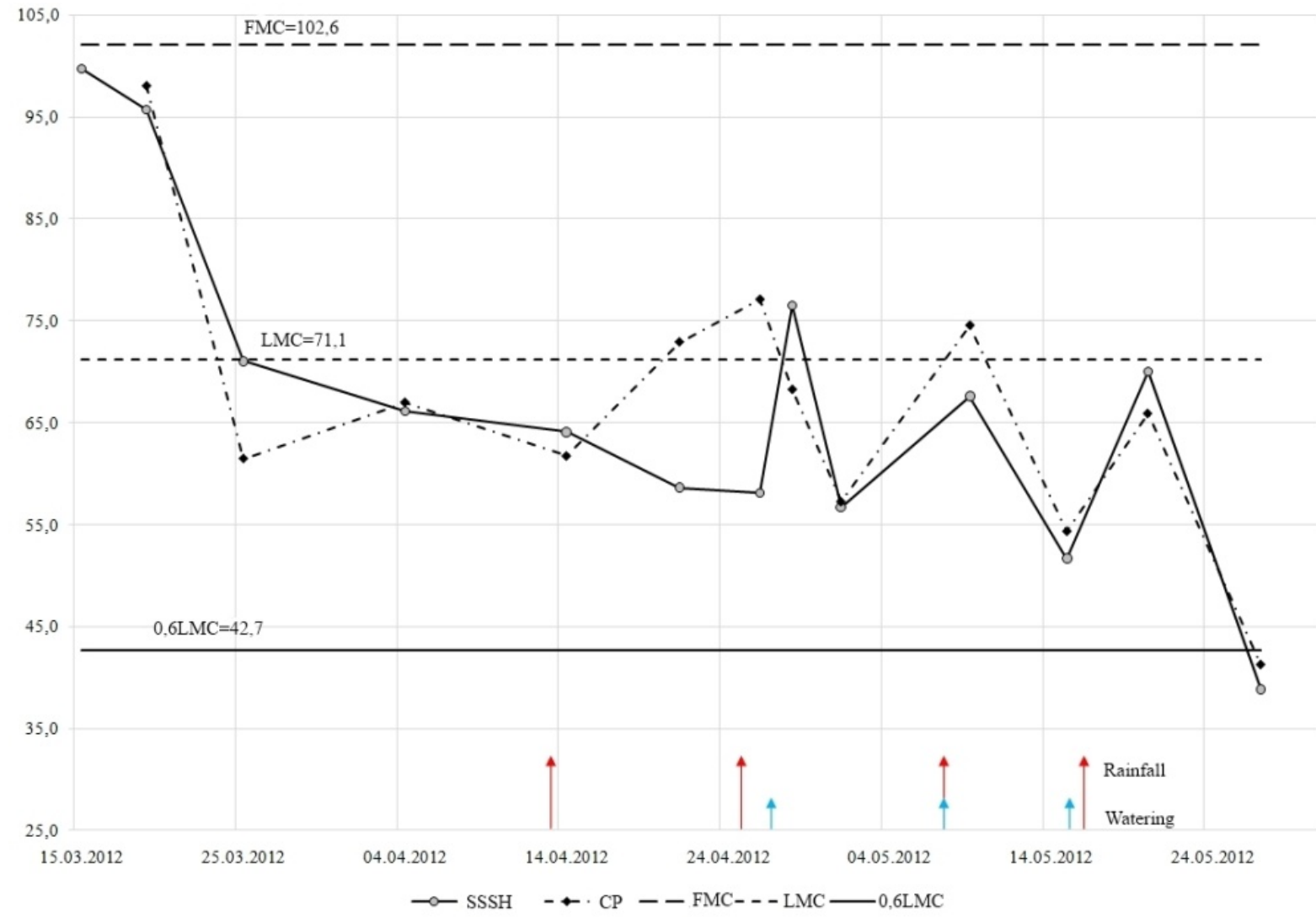

b)

Figure 8. The dynamics of soil humidity ( $\mathrm{mm}$ ) in the layer 0-0.2 m within: a) 2011 year; b) 2012 year. 
The features of the formation of soil humidity depending on the location of the shell- sleeves have been uncovered. So, in the middle of the plot ( area between the second and the third, the third and the fourth sleeves, see Picture 5) is observed the greatest waste of humidity and at the edges of shelter (area between the first and the second sleeves and area between the fourth and the fifth sleeves ) the largest dry is remained.

At the present stage of development of agricultural melioration the most perspective way of irrigation, both in design and technological features, and with the focus on resource conservation is a drip method. In comparison with traditional irrigation methods, drip irrigation is the most completely qualified for energy and resource preservation, and not least, the ecological security of irrigation owing to the ability of dosing of irrigation water with dissolved nutrients, trace elements, and the local nature of soil humidity. However, the characteristics of this method of irrigation require to control dynamics of properties of soil humidity in plot. The intensity and direction of groundwater processes depend on the quantity and quality of irrigation water, irrigation regime, and quantity and regime of falling autumn and winter precipitation $[17,18]$.

Drip irrigation was performed with drip tape type T-Tape with the following parameters: thickness of wall $175 \mathrm{~mm}$, diameter $16 \mathrm{~mm}$, flow drip 0,5 - 0,75 $\mathrm{l} / \mathrm{h}$, working pressure of $0.75 \mathrm{~atm}$, the distance between the integrated droppers 10 $\mathrm{cm}$

The water from the reservoir, which was located at a height of $4 \mathrm{~m}$, was fed to the collector through a pipeline to disburse it to the drip tape. The amount of water, which was fed into the system, was defined by water meter HF-1,5, supplying of water was regulated by valve.

In 2011 the first irrigation was held on April 30- th by rate $200 \mathrm{~m}^{3} /$ ha. This has increased the holard in the layer $0-10 \mathrm{~cm}$ to $28.3 \mathrm{~mm}$, and in the layer $0-50 \mathrm{~cm}$ to $155.4 \mathrm{~mm}$. Later there was a need to refill holard again in the soil. Watering was held on 9-th and 22-d May, 1-st June by rate $200 \mathrm{~m}^{3} / \mathrm{ha}$.

\section{Conclusion}

Analysis of data of the field experiment within 2011-2012 infers the following conclusions:

- general changes in soil humidity in the layer 0-50 cm is almost identical as on the control as on the heating surface, but keeping up of optimal humidity on the heating surface must be carried out by using a drip irrigation system;

- the intensity of the loss of humidity on the heating surface increases with increasing the harvest of strawberries at the end of April and with increasing the intensity of tunnel' ventilation during the day;

- dynamics of holard in the layer $0-20 \mathrm{~cm}$ shows that top layer of soil which containing the root dries more strongly and it requires that the system of irrigating must be located on the soil surface.
- the significant difference of soil humidity in the area in the middle between the sleeves and the area near the outer sleeves is determined and it needs to consider when humid soil is heated by pipeline shell-sleeves.

It was determined that soil humidity can be maintained at the right level for plant growth, heating soil must be fed into additional humidity within $350-400 \mathrm{~m}^{3} / \mathrm{ha}$, and the level of humidity in the soil can be controlled by humidifying periodically the soil with small irrigation norms within to $100-150 \mathrm{~m}^{3} /$ ha, mainly during the second half of April and May, when tunnels start to ventilate and losses of moisture increase. The level of humidity in the soil is kept at a sufficient level without additional humidification when tunnels are closed in March and April.

\section{REFERENCES}

[1] De Walle D.R. Utilization and dissipation waste heat by soil warming // Prok. Gonf. Waste Heat. Manag. - 1976. - v. 2, VII A/73 - VIIA/86.

[2] Cook D., Norman J. Soil Warming as an Alternative to Conventional Waste-Heat Dissipation, - Journal of Enviroumental Qualification, - 1982, V. 11, № 1. - P. 46-52.

[3] Kendrick J., Havens J. Heat Transfer models for a subsurface water pipe soil warming system // J. Environ. Quality., V. 2, 1973, № 2. - P. 188-196.

[4] Skagss R.W. Use of Waste heat for soil warming in Noth Carolina. -Trans ASAE, St. Joseph., Mich., - 1976, V. 19, № 1. - P. 159-167.

[5] Hinze G.G. Einflus ganzjariger Bodenheizung auf Eigenschaften einer Parafraunerde sowie auf den pflanzenertrege // Piss. Universital Bonn.: 1986. - 165 as. 6. Lucow H., Reinken G. The Agrotherm Research Project. //Waste Heat Management and Utilization, Conf. - 1979, Wachington, V. 3, - P. 2395-2408.

[6] Mann E. Nutsung der Kuhlwasserwarme thermischer Kraftwerke // Energiewirtschaftliche Tagesfragen. - 1982, V. 32. - № 8 - S. 697-702.

[7] Schmid G. Verwertung der Abwarme von Kernkraftwerken in der Landwirtschaft. - Mitt. Dt. Bodenkunde, 1977, Bd 25, H 2. -S. 673-681.

[8] Muller-Feuga A. Valorisation des eaux ti'edes des centrals thermiqurs: agriculture, chauffage des locaux. - Electrisite de France, Paris, - 1980, - 41 as.

[9] Корольков Е.Д., Карпенко Б.Я. Использование низкотемпературных тепловых отходов электростанций в овощеводстве. - Известия ТСХА, 1970, в. 2. - С. 168-175.

[10] Использование теплых вод ТЭС и АЭС в народном хозяйстве. - Вестник АН СССР, 1975, № 12. - С. 68-75. 12. Кузьмич П.К., Ковалев С.В., Востриков В.П. Подпочвенные системы охлаждения циркуляционных вод электростанций в открытом грунте. Сб. научных трудов „Гидропроекта”. - Вып. 116. - С. 69-76. 
[11] Романюк І.В. Теплова меліорація грунту скидною теплою водою за допомогою системи 3 теплообмінниками-рукавами (в умовах Західного Полісся України ): дис. канд. техн. наук: 06.01.02. - Рівне, 2007. - 249c.

[12] Пінчук О.Л. Обгрунтування конструкції та параметрів гідротехнічної системи поверхневого обігріву грунту оболонками - рукавами при використанні скидних теплих вод: дис. канд. техн. наук: 06.01.02. - Рівне, 2012. $-255 \mathrm{c}$.

[13] Востріков В. П. Температурний режим дерново-слабопідзолистого грунту в умовах поверхневого обігріву водонаповненими рукавами / В. П. Востріков, І. В. Романюк, О. Л. Пінчук // Вісник НУВГП: збірник наукових праць. Частина 1. - Рівне, 2007. Випуск 4(40). - с. 224-231.
[14] Востріков В. П. Методика натурних досліджень роботи системи поверхневого обігріву грунту та автоматизованого збору температурних даних / В. П. Востріков, В. С. Мельник, О. Л. Пінчук, В. М. Гнатюк // Вісник НУВГП: збірник наукових праць. Серія «Технічні науки». - Рівне, 2011. - Випуск 2(54). - с. 40-49.

[15] Рябков С.В. Оцінка впливу краплинного зрошення на агрофізичні властивості, сольовий склад та солонцюватість грунтів // Агрохімія і грунтознавство. Міжвідомчий тематичний науковий збірник. - 2009. - № 71.

[16] Системи краплинного зрошення: [навчальний посібник] / M.I. Ромащенко, B.I. Доценко, Д.М. Онопрієнко, O.I Шевелев - Дніпропертовськ: ООО ПКФ «Оксамит-текст», 2007. $-175 \mathrm{c}$. 